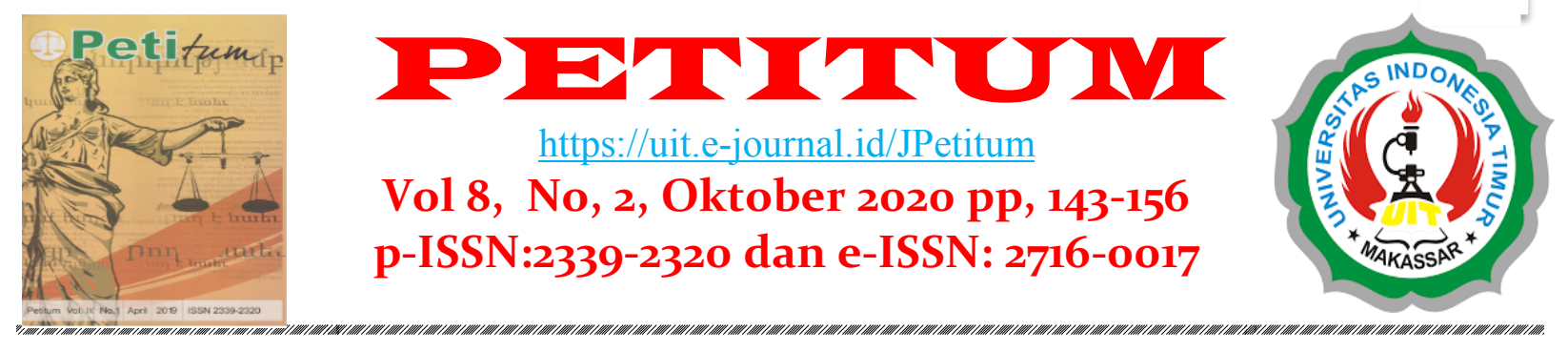

\title{
Pemetaan Sertipikat Secara Digital (Plotting) dalam Memberikan Kepastian Hukum Terhadap Hak Atas Tanah
}

\author{
Mashita Amalia Razak', Farida Patittingi², Maskun ${ }^{3}$ \\ ${ }^{1}$ Magister Hukum, Universitas Hasanuddin, Email: razakshinta@yahoo.co.id \\ ${ }^{2}$ Fakultas Hukum, Universitas Hasanuddin, Email: farida.pada@unhas.ac.id \\ ${ }^{3}$ Fakultas Hukum, Universitas Hasanuddin, Email: maskun@unhas.ac.id
}

\begin{abstract}
Artikel info
Artikel history:

Received; 08-10-2020

Revised: 17-10-2020

Published: 22-10-2020

Keywords:

Land, Plotting,

Certificates, Land

Rights

ABSTRACT: The research aims to determine the implementation of the digital certificate mapping (plotting) policy in providing legal certainty for land rights. The research is empirical legal research. This research was conducted at the Data and Information Center of the Ministry of Agrarian and Spatial Planning/National Land Agency of Kendari City. The results showed that the implementation of digital certificate mapping (plotting) was carried out by inputting manual data of land certificates (both old certificates and newly issued certificates) into a digital registration map application based on Global Positioning System technology which aims to validate the correctness of certificate data. where the results will show the validity of the land parcel data according to the information in the certificate. In line with the negative land registration publication system with a positive tendency in Indonesia, plotting does not provide absolute legal certainty, but at least plotting can minimize the potential for land disputes that can arise in the future, including double or overlapping certificates.
\end{abstract}

\section{Kata Kunci:}

Tanah, Plotting, Sertifikat, Hak Atas Tanah
ABSTRAK: Penelitian bertujuan untuk mengetahui implementasi kebijakan pemetaan sertifikat secara digital (plotting) dalam memberikan kepastian hukum terhadap hak atas tanah. Penelitian adalah penelitian hukum empiris. Penelitian ini dilakukan di Pusat Data dan Informasi Kementerian Agraria dan Tata Ruang/Badan Pertanahan Nasional Kota Kendari. Hasil penelitian menunjukkan bahwa implementasi pemetaan sertipikat secara digital (plotting) dilakukan dengan menginput data manual sertipikat tanah ke dalam dalam aplikasi peta pendaftaran digital yang berbasis teknologi Global Positioning System yang bertujuan memvalidasi kebenaran dari data sertifikat sebagai validitas data bidang tanah telah sesuai keterangan di sertifikat. Sejalan dengan sistem publikasi pendaftaran tanah negatif bertendensi positif, plotting belum memberikan kepastian hukum secara absolut akan tetapi setidaknya plotting dapat meminimalisir potensi sengketa tanah, di antaranya sertipikat ganda atau tumpang-tindih.

Coresponden author:

Email: razakshinta@yahoo.co.id artikel dengan akses terbuka dibawah lisensi CC BY 
Pemetaan Sertipikat Secara ... (Razak, Patitting \& Maskun) | 144

\section{PENDAHULAN}

Dalam konteks negara, tanah sebagai bagian permukaan bumi, mempunyai arti yang sangat penting dalam kehidupan suatu bangsa, baik sebagai tempat atau ruang untuk kehidupan dengan segala kegiatannya, sebagai sumber kehidupan, bahkan sebagai suatu bangsa, tanah merupakan unsur wilayah dalam kedaulatan negara. Oleh karena itu, tanah bagi bangsa Indonesia mempunyai hubungan abadi dan bersifat magis religius, yang harus dijaga, dikelola, dan dimanfaatkan dengan baik. Dengan demikian, diperlukan penanganan dan pengaturan yang serius dan seksama (Limbong, 2012).

Dalam perjalanan sejarah bangsa Indonesia, tanah telah menjadi salah satu bagian dari pembangunan hukum yang menarik. Hal ini terutama karena sumber daya tanah langsung menyentuh kebutuhan hidup dan kehidupan manusia dalam segala lapisan masyarakat, baik sebagai individu, anggota masyarakat dan sebagai suatu bangsa (Sutedi, 2008). Asas domain sebagai dasar hukum memungkinkan Negara selaku pemilik tanah memberikan hak atas tanah kepada pihak lain dalam kedudukan sebagai badan hukum perdata. Jadi, bukan berkedudukan sebagai badan penguasa. Hak negara tersebut semata-mata hak perdata, sama dengan hak milik yang dipunyai perorangan.

Sebelum lahirnya hukum agraria kolonial, di Indonesia berlaku hukum tanah adat dan hukum tanah swapraja. Hukum tanah adat merupakan hukum asli, mempunyai sifat yang khas, di mana hak-hak perorangan atas tanah merupakan hak pribadi akan tetapi di dalamnya mengandung unsur kebersamaan, yang dalam istilah modern disebut fungsi sosial. Kebutuhan suatu hukum agraria yang menjamin kepastian dan perlindungan hukum hak-hak masyarakat dirasakan sangat mendesak dan sejak tanggal 24 September 1960 ditetapkan Undang-undang Nomor 5 Tahun 1960 tentang Peraturan Dasar Pokok-Pokok Agraria (selanjutnya disebut UUPA). Undangundang ini lahir setelah melalui proses yang cukup lama, menganut unifikasi hukum dan berdasarkan hukum adat.

Dalam rangka menjamin kepastian hak dan kepastian hukum atas tanah, UUPA telah menggariskan adanya keharusan untuk melaksanakan pendaftaran tanah di seluruh Indonesia (Ariandayu, A., \& Karjoko, L. (2019). Di samping itu, terselenggaranya pendaftaran tanah juga dimaksudkan terciptanya suatu pusat informasi mengenai bidang-bidang tanah sehingga pihak yang berkepentingan termasuk Pemerintah dengan mudah dapat memperoleh data yang diperlukan dalam mengadakan perbuatan hukum mengenai bidang-bidang tanah dan satuan rumah susun yang telah terdaftar. Terselenggaranya pendaftaran tanah secara baik merupakan dasar dan perwujudan tertib administrasi di bidang pertanahan (Hermit, 2004).

Adapun Sengketa agraria di Indonesia telah sampai pada tahap yang mengkhawatirkan, baik dari segi jumlah maupun bobot sengketanya. Menurut data tahun 2008 dari Konsorsium Pembaruan Agraria (KPA) terdapat sekitar 1.753 kasus sengketa yang terjadi di 2.834 Desa/Kelurahan, 1.355 Kecamatan dan 286 Kabupaten/Kota. Sebagai gambaran, bila digabungkan ribuan kasus itu mencakup luas lahan sekitar 10.892.203 Ha. Dengan intensitas konflik tertinggi di Jabar (484 kasus), DKI Jakarta (175 kasus), Jawa Timur (169 kasus) dan Sulawesi Selatan (85 kasus). 
Akibat adanya persengketaan di bidang pertanahan dapat menimbulkan konflikkonflik yang berkepanjangan antar warga masyarakat yang bersengketa (Maryana, 2016). Semuanya bermula dari pertanyaan-pertanyaan tentang siapakah yang lebih berhak atas tanah tersebut, sehingga para pihak berlomba-lomba membuktikan bahwa merekalah yang lebih berhak atas tanah tersebut. Dengan demikian sangat diperlukan adanya jaminan kepastian hukum dan kepastian hak atas kepemilikan tanah. Untuk mendapatkan jaminan kepastian hukum dan kepastian hak atas kepemilikan tanah, maka masyarakat perlu mendaftarkan tanah guna memperoleh sertifikat hak atas tanah yang berfungsi sebagai alat pembuktian yang kuat atas kepemilikan hak atas tanah.

Peraturan Menteri Agraria dan Tata Ruang/Kepala Badan Pertanahan Nasional Nomor 33 Tahun 2016 tentang Surveyor Kadaster Berlisensi yang salah satu kebijakannya mengatur tentang pemetaan sertifikat (plotting). Peraturan Menteri ini disusun berdasarkan asas kepastian hukum, perlindungan hukum, profesionalisme, transparansi, keadilan, serta etika dan pertanggungjawaban. Hasil survei dan pemetaan bidang tanah harus memenuhi persyaratan:

1) Dapat dipetakan dalam Peta Dasar Pendaftaran;

2) Bentuk dan ukuran sesuai dengan bentuk dan ukuran obyek sesungguhnya di lapangan;

3) Dapat direkonstruksi batas-batasnya di lapangan;

4) Tidak tumpang tindih sebagian maupun seluruhnya dengan hasil survei dan pemetaan sebelumnya.

Pemetaan bidang tanah adalah kegiatan pengolahan data dan penggambaran hasil pengukuran bidang-bidang tanah dengan suatu metode tertentu pada media tertentu sehingga letak dan ukuran bidang tanahnya dapat diketahui dari media tempat pemetaan bidang tanah tersebut.

Pelayanan pendaftaran hak atas tanah di seluruh Kantor Pertanahan Indonesia mengalami perubahan dengan kebijakan yang berlaku sejak September tahun 2016 tanpa adanya sosialisasi kepada pemohon/pengguna layanan Kantor Pertanahan. Kebijakan tersebut mewajibkan setiap sertifikat yang akan di proses di Kantor Pertanahan di seluruh Indonesia, dilakukan Plotting (Pemetaan Sertipikat secara Digital). Pelayanan pendaftaran tanah di Kantor pertanahan seperti Pengecekan sertifikat, Permohonan Surat Keterangan Pendaftaran Tanah (SKPT), Roya, Pendaftaran Hak Tanggungan, Pendaftaran Peralihan Hak atas Tanah (Balik Nama), permohonan Informasi Zona Nilai Tanah (ZNT), dan beberapa pelayanan pertanahan lainnya tidak dapat diterima dan diproses sebelum dilakukan Plotting sertifikat terlebih dahulu. Kebijakan ini menjadi kewajiban ini mutlak harus dijalankan, dan tidak diberikan toleransi, karena sistem kerja online dari Kantor Pertanahan yang sudah terintegrasi digital, tidak memperkenankan penginputan data permohonan pendaftaran tanah apabila sertifikat yang akan diproses statusnya belum pernah di plotting.

Kebijakan ini diberlakukan dalam rangka transformasi data fisik pertanahan yang sebelumnya masih manual ke dalam sistem yang berbasis digital, sesuai dengan instruksi Presiden agar pelayanan di bidang pertanahan segera berbasis digital. Salah satunya adalah peta bidang tanah digital (sebelumnya manual) yang dapat di akses oleh masyarakat. 
Plotting (pemetaan sertifikat secara digital) sejatinya dapat lebih memberikan kepastian hukum kepada pemegang hak atas tanah., sehingga tidak terjadi lagi kasus tumpang tindih sertipikat, atau sertipikat ganda yang selama ini masih sering terjadi karena pencatatan pendaftaran tanah masih manual. Pelaksanaan plotting khususnya di Kantor Pertanahan Kota Kendari, pemohon pendaftaran tanah baik oleh masyarakat umum (pemohon langsung), maupun dari Notaris dan/atau Pejabat Pembuat Akta Tanah (PPAT), kebijakan plotting ini dianggap cukup menghambat dan cenderung mempersulit pelayanan pendaftaran dan peralihan hak atas tanah. Hal ini disebabkan karena plotting ini membutuhkan proses yang cukup rumit dan lama. Belum lagi petugas yang melayani proses plotting masih terbatas, membutuhkan turun ke lokasi dan harus melayani begitu banyak permohonan, sehingga masih menjadi pekerjaan rumah yang panjang bagi BPN untuk melakukan plotting dengan pelayanan yang cepat dan efisien.

Tidak dapat dipungkiri, terdapat kecenderungan bahwa plotting sertipikat belum mampu memberikan kepastian hukum terhadap pemegang hak atas tanah, sebagaimana yang menjadi tujuan awal diadakannya peta digital bidang tanah, untuk memberikan kepastian hukum kepada pemegang hak atas tanah.

\section{METODE PENELITIAN}

Penelitian adalah penelitian hukum empiris (empirical legal research) (Nurdewata, 2010). Kajian empiris adalah kajian yang memandang hukum sebagai kenyataan, mencakup kenyataan sosial, kenyataan kultur, dan lainnya (Ali et al, 2012). Penelitian ini dilakukan di Kota Kendari Provinsi Sulawesi Tenggara, dengan sasaran pada pihak-pihak yang merupakan pihak pendukung dalam terciptanya kepastian hukum kepemilikan hak atas tanah melalui pendaftaran tanah (sertipikat) di Pusat Data dan Informasi Kementerian Agraria dan Tata Ruang/Badan Pertanahan Nasional Kota Kendari. Populasi dalam penelitian ini adalah keseluruhan pihak yang terkait dengan pendaftaran hak atas tanah terkait objek penelitian, yaitu Kantor Pertanahan Kota Kendari dan masyarakat pemegang hak atas tanah terkait. Penentuan sampel dilakukan dengan purposive sampling (Irwansyah, 2020). Data yang telah diperoleh melalui kegiatan penelitian dianalisis secara kualitatif kemudian disajikan secara deskriptif

\section{HASIL DAN PEMBAHASAN}

\section{A. Implementasi Sistem Pemetaan Sertipikat Secara Digital (Plotting)}

Dalam sejarah perkembangannya, kegiatan survei dan pemetaan setelah masa Kemerdekaan Indonesia pertama kalinya dilaksanakan berdasar Peraturan Pemerintah Nomor 71 Tahun 1951 tentang Pembentukan Dewan dan Direktorium Pengukuran dan Penggambaran Peta. Selanjutnya, kegiatan survei dan pemetaan dipertegas lagi dengan Keputusan Presiden Nomor 263 tanggal 7 September 1965 tentang Pembentukan Dewan Survei dan Pemetaan Nasional (Desurtanal) serta Komando Survei dan Pemetaan Nasional (Kosurtanal) sebagai pelaksana.

Dalam bidang agraria, berlakunya UUPA pada tahun 1960 dengan Peraturan Pemerintah Nomor 10 Tahun 1961 tentang Pendaftaran Tanah sebagai salah satu 
peraturan pelaksananya, mengatur bahwa setiap tanah harus didaftarkan. Pendaftaran tanah selain memuat data yuridis juga memuat data fisik yang diwujudkan dengan pemetaan bidang tanah yang dilaksanakan oleh BPN.

Dengan menggunakan teknologi yang manual pada saat itu, pelaksanaan pemetaan bidang tanah sejatinya telah mulai dilakukan untuk setiap pendaftaran bidang tanah sebagaimana yang dimaksud dalam Peraturan Pemerintah Nomor 71 Tahun 1951 tentang Pembentukan Dewan dan Direktorium Pengukuran dan Penggambaran Peta. Berdasarkan wawancara penulis dengan Haeruddin, S.H mengataan bahwa pemberlakuan mekanisme plotting sertipikat secara digital telah diberlakukan sejak tahun 2012. Program ini lahir untuk mendukung kebijakan pemerintah lewat Arah Kebijakan Pembangunan Nasional pada tahun 2010. Plotting merupakan salah satu implementasi kebjiakan Pemerintah Republik Indonesia yang dilaksanakan BPN sebagai pemangku kebijakan di bidang Pertanahan melalui Kantor pusat, Kantor Wilayah dan Kantor Pertanahan di setiap daerah.

Sebagaimana tugas pokok BPN adalah melaksanakan tugas pemerintah di bidang pertanahan sesuai dengan ketentuan peraturan perundang-undangan dan dalam menjalankan tugasnya tersebut BPN berfungsi di antaranya:

1. Penyusunan dan penetapan kebijakan di bidang pertanahan,

2. Perumusan dan pelaksanaan kebijakan dibidang survei, pengukuran, dan pemetaan,

3. Perumusan pelaksanaan kebijakan di bidang penetapan hak atas tanah, pendaftaran tanah, dan pemberdayaan masyarakat, dan

4. Perumusan pelaksanaan kebijakan bidang pengendalian dan penanganan sengketa dan/atau perkara pertanahan.

Menurut hemat penulis, program Plotting lahir untuk menjalankan tugas BPN yaitu memvalidasi dan integrasi data manual bidang tanah menjadi sistem data yang berbasis peta digital sertipikat hak atas tanah. Haeruddin, S.H mengataan bahwa penyimpanan data dan gambar bidang tanah secara manual hanya tersimpan pada arsip buku tanah dan/atau peta blok tanah pada setiap Kantor Pertanahan setempat yang menerbitkan sertipikat. Sehingga salah satu sasaran pelaksanaan plotting secara digital ini menyasar data-data lama yang masih manual, sebagai langkah penyelarasan dengan data yang sudah terintegrasi sistem digital pada sistem Komputerisasi Kegiatan Pertanahan (KKP) yang dimiliki BPN. Penyelarasan antara data yang baru dengan data lama bidang tanah yang belum terinput/tervalidasi ditindaklanjuti pihak BPN dengan melakukan pendataan ulang yang dilanjutkan dengan validasi data kemudian diintegrasi ke dalam sistem KKP melalui program PTSL ( Pendaftaran Tanah Sistematis Lengkap).

Dalam wawancara peneliti dengan Tageli Lase, dikemukakan bahwa dahulu pemetaan sertipikat masih menggunakan sarana yang sederhana (tradisional), dengan salah satu kelemahannya adalah akurasi dari data tersebut, yang seringnya masih perlu untuk ditinjau kembali. Berbeda dengan sistem saat ini, seiring perkembangan zaman, teknologi yang digunakan semakin mutakhir dan canggih, sehingga dalam akurasi data jauh semakin baik, hal ini berdampak baik dalam menunjang kinerja pelayanan BPN kepada masyarakat dalam memberikan kepastian akan data tanah. Pembaharuan sistem untuk menunjang efektifitas dari pemetaan tanah secara Nasional dengan optimal. 
Plotting terhadap bidang tanah untuk sertipikat pada dasarnya merupakan implementasi dari Program Kebijakan Satu Peta yang menjadi program pemerintah secara Nasional. Melalui Program Kebijakan One Map Policy (OMP) yang dipilih oleh pemerintah Indonesia sebagai bentuk upaya telaksananya tujuan daripada poin pertama Isu Strategis di dalam Rencana Pembangunan Jangka Menegah Nasional (RPJMN) tersebut, Program Kebijakan One Map Policy (OMP), dalam pelaksanaannya, kemudian melahirkan suatu sistem administrasi digital melalui Badan Pertanahan Nasional dimana penerapannya, diperkenalkan kepada masyarakat sebagai mekanisme plotting yang dilaksanakan oleh Kantor Pertanahan, yang secara fungsionalnya mengintegrasikan sistem pemetaan konvensional (manual) menjadi sistem pemetaan modern (digital) atau yang juga disebut sebagai Kebijakan Komputerusasi pada Badan Pertanahan Nasional, yang diselaraskan dengan Program Kerja Badan Pertanahan Nasional yakni Reformasi Agraria di bawah pemerintahan Presiden Joko Widodo, sebagaimana Peraturan Presiden Nomor 9 Tahun 2016 tentang Percepatan Pelaksanaan Kebijakan Satu Peta (KSP) pada Tingkat Ketelitian Peta Skala 1:50.000 yang mengacu pada referensi geospasial, satu standar, satu basis data, dan satu geoportal guna percepatan pelaksanaan pembangunan nasional, yang dikeluarkan pada tanggal 1 Februari 2016.

Berdasarkan penjelasan tersebut di atas, menurut penulis karena plotting merupakan kebijakan Nasional dari pemerintah dalam bidang Agraria melalui Kantor Pertanahan maka BPN mempunyai kewajiban untuk memplotting seluruh bidang tanah di Indonesia. Hal ini sekaligus merupakan bagian daripada pelayanan kepada masyarakat yang menjadi tugas pokok dan fungsi BPN.

Idealnya pelaksanaannya harus dilakukan dalam kurun waktu yang tidak terlalu lama, akan tetapi menurut Haeruddin S.H secara kuantitas jumlah bidang tanah dan sertipikat yang akan diplotting sangat banyak, khususnya sertipikat lama (yang masih manual pembukuannya) menyebabkan dibutuhkan waktu yang cukup lama untuk menginput bidang sertipikat tersebut. Belum lagi hambatan-hambatan timbul, ketidaksesuain data fisik dan data yuridis dengan data di lapangan. Oleh karena itu, pelaksanaan Kebijakan Satu Peta khususnya di bidang Pertanahan, merupakan tantangan yang cukup berat bagi instansi BPN, ditambah dengan respon masyarakat dalam menanggapi hadirnya program ini juga menjadi salah satu faktor kendalanya.

Dalam wawancara peneliti dengan Tageli, dikemukakan bahwa pelaksanaan plotting sertipikat pada kantor Pertanahan telah berjalan sejak tahun 2012, khususnya terhadap penerbitan sertipikat baru, baik secara sporadik maupun sistematis sudah mulai diplotting terlebih dahulu. Pada tahapan penerbitan sertipikat baru pelaksanaan pengukuran tanah terlebih dahulu diplotting sebelum diterbitkan surat ukur. Sehingga terhitung sejak 2012, tidak ada lagi penerbitan sertipikat baru tanpa melewati mekanisme plotting terlebih dahulu.

Lebih lanjut dikemukakan Tageli, bahwa sejak saat itu pula Kantor Pertanahan setiap daerah memulai penginputan data fisik dan data digital sertipikat lama secara berkala untuk dikonversi menjadi data digital. Khusus untuk penginputan data-data sertipikat lama, prosesnya telah berjalan tetapi progresnya cukup lambat, mengingat jumlah sertipikat lama yang masih data manual sangat banyak jumlahnya.

Menurut penulis, banyaknya jumlah sertipikat tanah yang diterbitkan terhitung sejak berlakunya UUPA sejak tahun 1960 dengan salah satu wujud pelaksanaan 
adalah pendaftaran tanah, hingga tahun 2012 menjadi pekerjaan yang sangat berat. Melakukan pendataan kembali terhadap sertipikat manual yang telah diterbitkan secara berkala lebih kurang 50 (lima puluh) tahun adalah tantangan besar dan bukan pekerjaan yang mudah bagi Kantor Pertanahan. Disamping itu, arsip dan data-data lama yang berusia puluhan tahun tidak dapat dijamin kondisinya masih layak dan aktual dijadikan bahan data.

Adapun menurut Haeruddin, bahwa target dari program pemerintah pusat sebagaimana yang tertuang di dalam Rencana Pembangunan Jangka Menegah Nasional (RPJMN), pemerintah menargetkan pada tahun 2024 telah dapat terlaksana secara menyeluruh, karena progress yang cukup lambat, maka untuk dapat memenuhi target, salah satu cara percepatan Kebijakan Satu Peta khususnya di bidang Pertanahan adalah kebijakan perubahan pelayanan pendaftaran Hak atas tanah di seluruh Kantor Pertanahan Indonesia yang berlaku sejak September tahun 2016, berdasarkan Surat Edaran Nomor 13/SE/XII/2017 tentang Pemanfaatan Aplikasi Layanan Pertanahan "Sentuh Tanahku". Kebijakan tersebut mewajibkan setiap sertipikat yang akan di proses di Kantor Pertanahan harus di Plotting terlebih dahulu tanpa kecuali. Sebelum September tahun 2016, pelayanan pendaftaran tanah tetap bisa diproses meski tanpa dilakukan plotting terlebih dahulu.

Lebih lanjut dikemukakan oleh Haeruddin, bahwa kebijakan ini menjadi kewajiban ini mutlak harus dijalankan, dan tidak diberikan toleransi, karena sistem kerja Komputerisasi Kegiatan Pertanahan yang online dari Kantor Pertanahan yang sudah terintegrasi digital, tidak memperkenankan penginputan data permohonan pendaftaran tanah apabila sertipikat yang akan diproses statusnya belum pernah di plotting.

Menurut penulis, meskipun kebijakan ini banyak menemui kritik dari masyarakat, karena dianggap menghambat pelayanan masyarakat, akan tetapi untuk jangka panjang sangat bermanfaat bagi masyarakat itu sendiri, misalnya mencegah dan meminimalisir tumpang tindih sertipikat. Sehingga penting dilakukan kebijakan yang kurang populis apabila ingin mencapai target digitalisasi yang lebih cepat. Hal ini dapat dilihat dari meningkatnya inisiatif masyarakat untuk plotting bidang tanah yang dimiliki.

\section{B. Kepastian Hukum Sertipikat Hak Atas Tanah Yang Telah Dilakukan Pemetaan Sertipikat Secara Digital (Plotting)}

Secara umum perlindungan hukum dalam plotting tampaknya belum dapat memberikan kepastian hukum secara sempurna, hal ini disebabkan Plotting online yang ditetapkan oleh pemerintah sebagai kebijakan One Map Policy sebagaimana yang tertuang di dalam arah kebijakan pembangunan Nasional dan visi pemerintah Indonesia dalam rangka peningkatan pengelolaan Pertanahan dan administrasi Pertanahan yang dilaksanakan oleh Badan Pertanahan Nasional (BPN). Pada pratiknya sejauh ini baru sebatas memberikan sistem administrasi yang terintegrasi secara digital online yang itu dimaksudkan sebagai media publikasi terkait informasi status kepemilikan Hak atas tanah, namun belum memberikan kekuatan hukum yang bersifat pasti sebab tidak tersedianya regulasi yang mengikat pada rencana tersebut. dengan demikian media yang digunakan dalam hal ini peta digital tersebut 
terkesan menyediakan data yang bersfiat inkonsten dikarenakan data yang tersedia secara online dengan objek lahan yang meski telah terplotting masih dapat berubah.

Pada kasus Kusno Ali, pemilik sebidang tanah kosong sebagaimana termuat dalam Sertipikat Hak Milik 00137, Kelurahan Watubangga, Kecamatan Baruga, Kota Kendari, seluas $95.918 \mathrm{M}^{2}$, tercatat atas nama Kusno Ali, yang tanah tersebut telah dibeli sejak tahun 1979, dan diterbitkan sertipikat untuk pertama kalinya atas nama Kusno Ali pada tahun 2007. Pada tahun 2010 sebagian tanah dari Kusno Ali \pm $20.000 \mathrm{M}^{2}$, tanpa sepengetahuan maupun persetujuan dari Pihak Kusno Ali, oleh Pihak Developer telah dibangun Perumahan Pelangi Golf Garden. Pihak Developer mengklaim juga memiliki sertipikat atas tanah yang dibanguni perumahan tersebut. Atas keterangan kedua belah pihak tersebut, terdapat indikasi tumpang tindih sebagian sertipikat milik Kusno Ali tersebut.

Selanjutnya, pada tahun 2017 Kusno Ali melakukan permohonan plotting pemetaan Sertipikat Hak Milik 00137/Watubangga tersebut ke Kantor Pertanahan Kota Kendari, dan dari hasil plotting menunjukkan keseluruhan peta digital menunjukkan Kusno Ali adalah pemilik sah atas $95.918 \mathrm{M}^{2}$ sesuai dengan surat ukur dalam sertifikat tersebut, termasuk pula bagian tanah yang telah dibanguni oleh Pihak Developer. Pada Peta Digital dari Aplikasi Digital Badan Pertanahan Nasional, Sertipikat Hak Milik 00137/Watubangga tercatat atas nama Kusno Ali, terlihat secara nyata terdapat bangunan pihak depelover.

Menurut Haeruddin, bahwa benar pelaksanaan plotting pada Sertipikat Hak Milik 00137/Watubangga milik Kusno Ali, telah dilakukan Petugas Kantor Pertanahan Kota Kendari pada tahun 2017, namun kemungkinan plotting yang dilakukan pada saat kurang lengkap. Hanya berdasarkan keterangan dari pihak Kusno Ali meskipun peninjauan lapangan oleh petugas dari Kantor Pertanahan Kota Kendari. Akan tetapi mungkin terkendala belum lengkapnya data dan kurangnya informasi dari pihak lain sehingga Kantor Pertanahan melakukan plotting atas permohonan Kusno Ali tersebut, meskipun terdapat indikasi tumpang tindih.

Atas informasi dari Peneliti, Haeruddin mengucapkan terima kasih kepada peneliti, karena informasi kasus dari penelitian ini Kantor Pertanahan Kendari mendapatkan masukan informasi positif dari masyarakat. Pada saat itu juga dilakukan pengkajian kembali atas data plotting Sertipikat Hak Milik 00137/Watubangga yang dilanjutkan dengan pengecekan kembali di lapangan oleh Petugas Kantor Pertanahan. Setelah pengumpulan pengkajian ulang data, Kantor Pertanahan melakukan perubahan data plotting tanah milik Kusno Ali seperti dapat dilihat pada perbandingan gambar 1 .

Pada gambar sebelah kiri, adalah gambar hasil plotting sebelum peneliti melakukan penelitian. Tampak pada gambar plotting bentuknya masih sesuai dengan surat ukur yang tertera dalam Sertipikat Hak Milik 00137/Watubangga. Sedangkan pada gambar di sebelah kanan adalah gambar plotting setelah peneliti memberikan informasi kepada Kantor Pertanahan Kota Kendari, yang ditindaklanjuti dengan melakukan perubahan gambar plotting. Tampak perubahan gambar plotting dengan tidak terplottingnya lagi tanah yang lokasi Perumahan Pelangi Golf Garden.
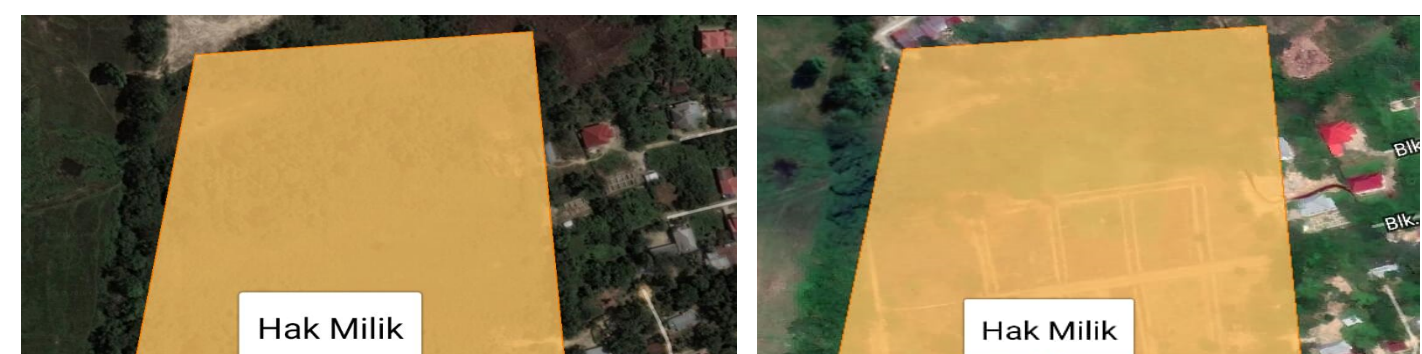
Apabila objek plotting yang dimaksudkan terjadi klaim kepemilikan dari pihak yang berbeda di waktu mendatang, sebagaimana contoh kasus yang ditampilkan oleh peneliti pada gambar di bawah ini dengan pemohon, Kusno Ali pada Kecamatan Baruga, Kecamatan Watubangga, Kota Kendari.

Lain halnya dengan kasus yang dialami oleh Abdul Rahim, pemilik sebidang tanah kosong sebagaimana termuat dalam sertipikat Hak Milik 01088, Kelurahan LepoLepo, Kecamatan baruga, Kota Kendari, seluas $7.131 \mathrm{M}^{2}$ (tujuh ribu serratus tiga puluh satu meter persegi), tercatat atas nama Abdul Rahim, yang mana tanah tersebut telah dibeli sejak tahun 1994, dan diterbitkan sertipikat untuk pertama kalinya atas nama Abdul Rahim pada tahun 1995. Pada tahun 2019 Abdul Rahim melakukan permohonan plotting pada Kantor Pertanahan Kota Kendari. Setelah pengambilan data di lapangan oleh petugas Kantor Pertanahan Kota Kendari, tanah tersebut akhirnya terplotting dan dapat diakses di aplikasi sentuh tanahku BPN.

Abdul Rahim menganggap bahwa tanah yang dimilikinya telah bersertipikat dengan status telah terplotting merasa telah mempunyai kepastian hukum, ia sehingga bermaksud membangun perumahan di atas lahan tersebut. Pekerjaan persiapan pembangunan perumahan telah berlangsung, akan tetapi pada saat akan melakukan proses pemecahan sertipikat, ternyata permohonan ditolak/tidak dapat diproses oleh Kantor Pertanahan dengan alasan bidang tanah belum terplotting. Setelah dikonfirmasi melalui Kepala Seksi Infrastruktur Pertanahan, ternyata plotting atas tanah tersebut telah di hapus dari sistem aplikasi digital BPN dikarenakan adanya pihak lain yang mengadukan ke Kantor Pertanahan bahwa bidang tanah yang di bangun perumahan adalah miliknya berdasarkan sertipikat Nomor 116, Kelurahan Lepo-Lepo, Kecamatan Baruga, Kota Kendari. Adapun perbedaan screenshoot pada aplikasi Sentuh tanah ku BPN terhadap sertipikat Hak Milik 01088/ Lepo - Lepo adalah sebagai berikut:

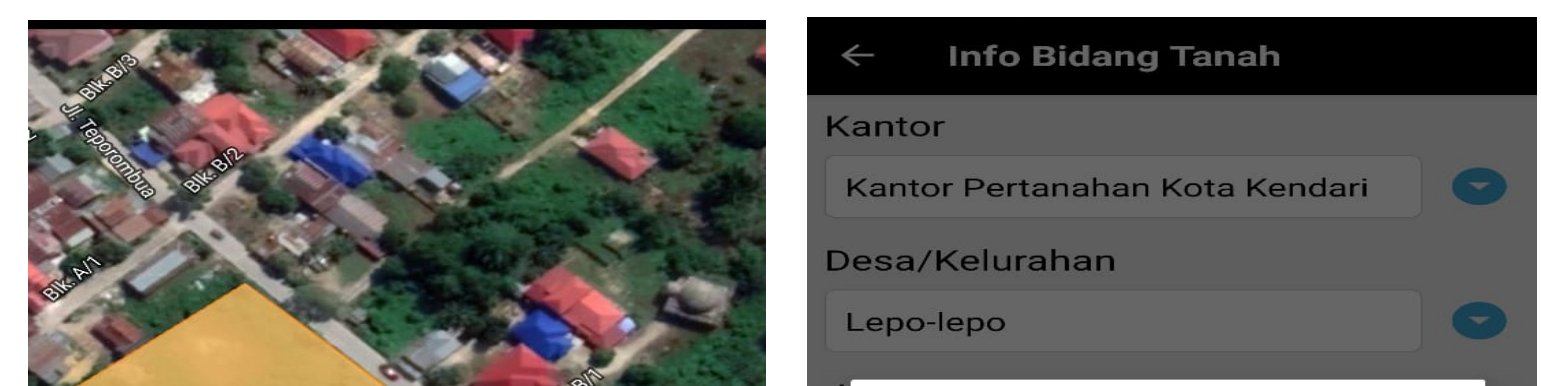


Gambar 2. Screenshoot pada aplikasi Sentuh tanah ku BPN terhadap sertipikat Hak Milik 01088/ Lepo - Lepo Sumber Data Primer, (diolah)

Pada gambar di sebelah kiri, adalah gambar yang diambil pada bulan Februari 2020, yang mana pada Peta Digital dari Aplikasi Digital BPN, sertipikat Hak Milik Nomor 01088/ Lepo - Lepo masih dapat diakses gambar digitalnya. Sedangkan pada gambar disebelah kanan, adalah hasil screenshot yang diambil pada bulan Maret 2020, yang mana peta digital sudah tidak dapat ditemukan, dengan kata lain sertipikat tersebut belum terplotting. Terhadap pelaporan tersebut, Kantor Pertanahan Kota Kendari menganggap terdapat indikasi tumpang tindih sertipikat milik Abdul Rahim tersebut. Sebagaimana pernyataan di dalam bukunya Soerjono Sukanto mengenai diperlukannya keselarasan kebijakan pelayanan masyarakat dengan landasan hukum yang pasti demi menjamin optimalnya kebijakan plotting ini di masyarakat. Penegakan hukum akan menjadi tidaklah berjalan sebagaimana mestinya atau akan terganggu dalam perjalanan dan penegakan hukumnya. Masalah pokok penegakan hukum terletak kepada faktor-faktor yang mempengaruhinya. Faktor-faktor tersebut adalah pertama, faktor hukumnya, kedua faktor penegak hukum, ketiga, faktor sarana atau fasilitas, keempat faktor masyarakat dan kelima faktor kebudayaan (Soekanto, 2008). Sehingga penulis berasumsi pentingnya dukungan regulasi hukum yang secara eksplisit mengatur tentang plotting ini demi menjamin kinerja optimal Kantor Pertanahan dalam menjalankan program kebijakan plotting tersebut, mengingat perkembangan dan efektifitas dari pada program ini telah cukup membuktikan manfaat positif baik bagi masyarakat maupun pemerintah, sehingga dengan dukungan peraturan yang tetap, mekanisme plotting ini tentu dapat memberikan kepastian hukum yang terintegrasi langsung dalam sistem instansi Kantor Pertanahaan sehingga dokumen/gambar situasi tersebut dapat mewakilkan dokumen otentik/alas hak yang berupa sertipikat.

Sebagai sebuah sistem yang dirujuk sebagai infrastruktur pelayanan publik (Patawari, P., Bakhri, S., \& Mery, L., 2020), tidak adanya regulasi hukum yang bersifat mengikat dalam kebijakan program plotting membuat program ini belum dapat memberikan dampak penataan administratif yang lebih baik dari sebelumnya bagi 
masyarakat dan pemerintah dalam mengadminstrasi data dengan lebih baik, meskipun demikian program yang sejatinya sejauh ini telah memberikan manfaat yang dinilai cukup baik dalam peningkatan mutu pelayanan, menurut penulis, akan menjadi suatu perkembangan yang bertendensi baik dalam penataan sistem administratif dan sistem hukum apabila pemanfaatannya sebagai suatu media yang difungsikan sebagai suatu langkah preventif hukum dalam meminimalisir tingginya persentasi angka persoalan sengketa di waktu mendatang, plotting online yang ditetapkan oleh pemerintah sebagai kebijakan One Map Policy yang dilaksanakan oleh Badan Pertanahan Nasional (BPN) pada prakteknya, sejauh ini hanya berdampak pada sistem administrasi yang terintegrasi dari yang dulunya konvensional (manual) menjadi sistem modern (digital online) yang difungsikan sebagai media publikasi terkait kepemilikan Hak atas tanah.

Komponen pada media yang digunakan dalam hal ini peta digital dengan objek lahan yang telah terplotting pada prakteknya masih dapat berubah apabila objek plotting yang dimaksudkan mendapat klaim kepemilikan dari pihak yang berbeda di waktu mendatang sehingga data-data yang telah terdistribusi sebagai informasi kepada masyarakat melalu instansi resmi pemerintah ini justeru terkesan sebagai data atau informasi yang inkonsiten, yang mana tentunya hal ini dapat berpotensi menimbulkan polemik perdebatan di masyarakat. Sehingga pentingnya program ini dilandaskan dengan ketentuan-ketentuan hukum dalam pelaksanaan hingga penerapannya. Kecendrungan permasalahan yang lain pula penulis asumsikan dapat pula terjadi bila program ini tidak difaslitasi dengan ketentuan dan mekanisme hukum dalam tata pelaksanaan plotting tersebut, ialah tendensi terbukanya ruang dan kesempatan bagi para oknum untuk melakukan tindakan penyerobotan lahan dengan menyalahgunakan sistem dan data yang ada, sehingga akan sangat riskan terjadi persoalan-persoalan yang tidak diinginkan di masa mendatang.

Penegasan dari pada penjelasan mengenai efektifitas pada sistem plotting ini, menurut M. Yusuf, mengatakan bahwa dengan adanya sistem ini persoalan mengenai tumpang tindih lahan yang umumnya terjadi dikarenakan induk data yang tidak tersentral dan tidak seakurat sistem teknologi digital, cenderung membuat tidak adanya sinkronisasi serta perbanding data yang ada maka dengan adanya sistem data dengan Margin of Error yang kecil ini sangatlah mendukung upaya menghindari kasalahan-kesalahan seperti yang terjadi di masa lalu oleh karena itu. Dengan keterangan tersebut, memperkuat asumsi peneliti bahwa inisiasi daripada program digital ini adalah langkah yang dipilih sebagai respon perbaikan dan penataan sistem hukum dalam bidang pertanahan di Indonesia, demi menciptakan efektifitas hukum yang lebih baik dan memedai dengan menyelaraskan perkembangan teknologi dalam menunjang perbaikan sistem administrasi pertanahan sebagai respon pencegahan pelanggaran hukum yang sering terjadi dalam bidang pertanahan di indonesia.

\section{KESIMPULAN}

Implementasi pemetaan sertipikat secara digital (plotting) dilakukan dengan menginput data manual sertipikat tanah (baik sertipikat lama maupun sertipikat yang baru diterbitkan) ke dalam dalam aplikasi peta pendaftaran digital yang berbasis teknologi Global Positioning System yang bertujuan memvalidasi kebenaran dari data sertifikat yang mana hasilnya akan menunjukkan validitas data bidang 
tanah telah sesuai keterangan di sertifikat. Efektivitas plotting secara umum telah berjalan cukup efektif dengan indikator kasus sertipikat tanah yang telah terplotting kemudian bermasalah tidak signifikan jumlahnya, dibandingkan dengan bidang tanah yang telah terplotting dan tidak bermasalah. Sejalan dengan sistem publikasi pendaftaran tanah negatif bertendensi positif di Indonesia, plotting belum memberikan kepastian hukum secara absolut karena masih dapat ditinjau kembali dikemudian hari jika terdapat kekeliruan ataupun terdapat pihak yang keberatan atas validitas data hasil plotting yang dapat membuktian sebaliknya, akan tetapi setidaknya plotting dapat meminimalisir potensi sengketa tanah yang dapat timbul di kemudian hari diantaranya sertipikat ganda atau tumpang-tindih.

\section{SARAN}

Selain dukungan sumber daya manusia dan sarana prasarana yang memadai bagi Badan Pertanahan Nasional, perlu ditingkatkan partisipasi dan peran aktif dari masyarakat pemegang hak atas tanah yang bersertipikat masih data manual, dengan membantu Kantor Pertanahan melakukan permohonan plotting atas bidang tanahnya, yang dilengkapi dengan data-data yang valid dan akurat, agar kebijakan one map policy dapat tercapai sesuai dengan target yang dicanangkan Pemerintah.

\section{DAFTAR PUSTAKA}

\section{Buku :}

Limbong, B. (2012). Hukum Agraria Nasional, Jakarta : Margaretha Pustaka.

Sutedi, A. (2008). Peralihan Hak Atas Tanah dan Pendaftarannya, Jakarta: Sinar Grafika.

Hermit, H. (2004). Cara Memperoleh Sertipikat Tanah Hak Milik, Tanah Negara dan Tanah Pemda, Teori dan Praktek Pendaftaran Tanah di Indonesia. Penerbit Mandar Maju: Bandung.

Nurdewata, M.F. (2010). Penelitian Hukum Normatif Dan Empiris, Pustaka Pelajar, Yogyakarta.

Ali, A \& Heryani, W. (2012). Menjelajahi Kajian Empiris Tehadap Hukum, Prenadamedia Group, Jakarta.

Irwansyah. (2020). Penelitian Hukum, Pilihan Metode dan Praktik Penulisan Artikel, Yogyakarta: Mirra Buana Media.

Soekanto, S. (2008). Faktor - Faktor yang Mempengaruhi Penegakan Hukum, Jakarta: PT. Raja Grafindo Persada.

\section{Jurnal dan Makalah :}

Ariandayu, A., \& Karjoko, L. (2019). Implementasi Asas Terjangkau Pendaftaran Tanah Di Kabupaten Sukoharjo Untuk Mempercepat Pensertifikatan Tanah. Jurnal Repertorium, 6(1), 13.

Artika, I. G. K., \& Utami, W. (2020). Percepatan Pembenahan Data Bidang Tanah Kluster 4 melalui Survei Data Pertanahan. BHUMI: Jurnal Agraria dan Pertanahan, 6(1).

Patawari, P., Bakhri, S., \& Mery, L. (2020). Implementasi Penyediaan Fasilitas Umum Fasislitas Sosial Dalam Rangka Pembangunan Perumahan Di Kawasan 
Pemukiman. Petitum, 8(1 April), 80-88. https://doi.org/10.36090/jh.v7i2 Oktober.804

Utami, R. A. (2018). Tumpang Tindih Antara Izin Usaha Pertambangan dengan Hak Guna Usaha Perkebunan. Justitia Jurnal Hukum, 2(2).

Maryana, R. (2016). Penerapan Nilai Kearifan Lokal Dalam Pengelolaan Lingkungan Hidup. PETITUM, 4(2 Oktober), 67-74. Retrieved from https://uit.ejournal.id/JPetitum/article/view/400

\section{Peraturan Perundang-Undang :}

Peraturan Menteri Agraria dan Tata Ruang/Kepala Badan Pertanahan Nasional Nomor 33 Tahun 2016

Peraturan Pemerintah Nomor 10 Tahun 1961 Tentang Pendaftaran Tanah, https://www.atrbpn.go.id/Publikasi/Peraturan-Perundangan/PeraturanPemerintah/peraturan-pemerintah-nomor-10-tahun-1961-1021 Diakses tanggal 17 Maret 2020

Peraturan Pemerintah Republik Indonesia Nomor 71 Tahun 1951 Tentang Pembubaran "Raad En Directorium Voor Het Meeten Kaarteerrwezen" dan Pembentukan "Dewan Pengukuran dan Penggambaran Peta" dan "Direktorium untuk Pengukuran dan Penggambaran Peta " https:/ / peraturan.bpk.go.id/Home/Details/77836/pp-no-71-tahun-1951 Diakses tanggal 17 Maret 2020

Peraturan Presiden Nomor 20 Tahun 2015 tentang Badan Pertanahan Nasional.

Peraturan Pemerintah Republik Indonesia Nomor 71 Tahun 1951 Tentang Pembubaran "Raad En Directorium Voor Het Meeten Kaarteerrwezen" dan Pembentukan "Dewan Pengukuran dan Penggambaran Peta" dan "Direktorium untuk Pengukuran dan Penggambaran Peta " https:/ / peraturan.bpk.go.id/Home/Details/77836/pp-no-71-tahun-1951 Diakses tanggal 17 Maret 2020

\section{Website :}

Konsorsium Pembaruan Agraria (KPA), Catatan Akhir Tahun 2018 Konsorsium Pembaruan Agraria. http://kpa.or.id/publikasi/download/4ae36-catahu2018-kpa-edisi-peluncuran_.pdf, diakses tanggal 19 November 2019

Sejarah Badan Informasi Geospasial, Integritas, Kolaborasi, Profesional, Kerja Cerdas, dan Adaptif. https://www.big.go.id/sejarah/ Diakses tanggal 17 Maret 2020. 